University of Nebraska - Lincoln

DigitalCommons@University of Nebraska - Lincoln

1998

\title{
Occurrence of Pesticides in Shallow Groundwater of the United \\ States: Initial Results from the National Water-Quality
}

Assessment Program

\author{
Dana Kolpin \\ U.S. Geological Survey \\ Jake Barbash \\ U.S. Geological Survey \\ Robert Gilliom \\ U.S. Geological Survey
}

Follow this and additional works at: https://digitalcommons.unl.edu/usgsstaffpub

Part of the Earth Sciences Commons

Kolpin, Dana; Barbash, Jake; and Gilliom, Robert, "Occurrence of Pesticides in Shallow Groundwater of the United States: Initial Results from the National Water-Quality Assessment Program" (1998). USGS Staff -Published Research. 70.

https://digitalcommons.unl.edu/usgsstaffpub/70

This Article is brought to you for free and open access by the US Geological Survey at DigitalCommons@University of Nebraska - Lincoln. It has been accepted for inclusion in USGS Staff -- Published Research by an authorized administrator of DigitalCommons@University of Nebraska - Lincoln. 


\section{Occurrence of Pesticides in Shallow Groundwater of the United States: Initial Results from the National Water-Quality Assessment Program}

\author{
DANA W. KOLPIN* \\ U.S. Geological Survey, 400 South Clinton Street, Box 1230, \\ Iowa City, lowa 52244
}

\section{JACK E. BARBASH}

U.S. Geological Survey, 345 Middlefield Road, Mail Stop 470, Menlo Park, California 94025

\section{ROBERT J. GILLIOM}

U.S. Geological Survey, Placer Hall, 6000 J Street, Sacramento, California 95819-6129

The first phase of intensive data collection for the National Water-Quality Assessment (NAW QA) was completed during 1993-1995 in 20 major hydrologic basins of the United States. Groundwater land-use studies, designed to sample recently recharged groundwater (generally within 10 years) beneath specific land-use and hydrogeologic settings, are a major component of the groundwater quality assessment for NAWQA. Pesticide results from the 41 landuse studies conducted during 1993-1995 indicate that pesticides were commonly detec ted in shallow groundw ater, having been found at $54.4 \%$ of the 1034 sites sampled in agricultural and urban settings across the United States. Pesticide concentrations were generally low, with over $95 \%$ of the detections at concentrations less than $1 \mu \mathrm{g} / \mathrm{L}$. Of the 46 pesticide compounds examined, 39 were detected. The compounds detected most frequently were atrazine $(38.2 \%)$, deethylatrazine $(34.2 \%)$, simazine $(18.0 \%)$, metolachlor (14.6\%), and prometon (13.9\%). Statistic ally signific ant relations were observed between frequencies of detection and the use, mobility, and persistence of these compounds. Pesticides were commonly detected in both agricultural ( $56.4 \% ; 813$ sites) and urban ( $46.6 \% ; 221$ sites) settings. Frequent detections of pesticides in urban areas indicate that, as is the case with agricultural pesticide use in agricultural areas, urban and suburban pesticide use significantly contribute to pestic ide occurrence in shallow groundwater. Although pesticides were detected in groundwater sampled in urban areas and all nine of the agricultural land-use categories examined, significant variations in occurrence were observed among these categories. Maximum contaminant levels (MCLs) established by the U.S. Environmental Protection Agency for drinking water were exceeded for only one pesticide (atrazine, $3 \mu \mathrm{g} / \mathrm{L}$ ) at a single location. How ever, M CLs have been established for only 25 of the 46 pesticide compounds examined, do not cover pesticide degradates, and, at present, do not take into account additive or synergistic effects of combinations of pesticide compounds or potential effects on nearby aquatic ecosystems.
Introduction

The widespread use of synthetic organic pesticides over the pasthalf century has led to their detection in many hydrologic systems of the United States and other countries (1-4). Pesticide contamination of groundwater is an issue of national importance in the United States because groundwater is used for drinking water by about $50 \%$ of the population (5).

Numerous studies have examined the occurrence of pesticides in groundwater of the United States over the past three decades, particularly in agricultural areas (urban areas have seldom been sampled). However, the designs of past studies vary widely with respect to factors such as their analytical scope and sensitivity, the types of wells sampled, and the land uses targeted, making consistent comparisons and assessments at regional and national scales difficult (3). The National Water-Quality Assessment(NAWQA) examines groundwater and surface water quality on a national scale using a consistent study design with respect to these and other parameters $(6,7)$.

For each NAWQA Study Unit, groundwater quality is assessed using three principal study components (7): surveys of existing wells in major aquifers (aquifer surveys), studies focused on shallow groundwater underlying specific land uses (land-use studies), and investigations of groundwater quality along individual flow paths (flow path studies). A national assessment of groundwater quality-and the processes that control it-will ultimately be obtained by combining the results for all three study components from NAWQA Study-Unit investigations conducted across the country, building over time as Study Units are completed.

This paper describes the pesticide results from the first set of groundwater land-use studies ( 31 agricultural and 10 urban) conducted in the first 20 NAWQA Study U nits during 1993-1995. The objectives are (a) to provide an initial summary of the concentrations and frequencies of detection of pesticide compounds in shallow groundwater beneath agricultural and urban areas within a broad range of environmental settings across thenation and (b) to examine the extent to which pesticide occurrence in groundwater beneath agricultural and urban areas is related to variations in the use and the physical and chemical properties of these compounds. Once the assembly of data from the first 20 NAWQA Study Units has been completed, the analysis will expand to a more detailed examination of factors affecting pesticide occurrence in groundwater-including variations in hydrogeology, soil properties, well type, well construction, and agricultural management practices (e.g., irrigation and tillage).

\section{Materials and Methods}

The primary objective of each land-usestudy is to determine the quality of recently recharged groundwater (generally within the past 10 years) beneath a specific land-use and hydrogeologic setting (7). The land-use studies provide a direct assessment of the effects of specific, recent human activities on groundwater quality as well as an early warning of the potential for contamination of downgradient aquifers or nearby surface waters receiving groundwater discharge. To ensure that land-use study results from different Study Units are comparable, the groundwater sampling design of NAWQA employs consistent guidelines for selecting existing wells or locations for the installation of new wells (7-10). A

* Corresponding author e-mail: dwkolpin@usgs.gov; phone: (319)358-3614; fax: (319)-358-3606.

S0013-936X(97)00412-4 Not subject to U.S. copyright. Publ. 1998 Am. Chem.Soc. 


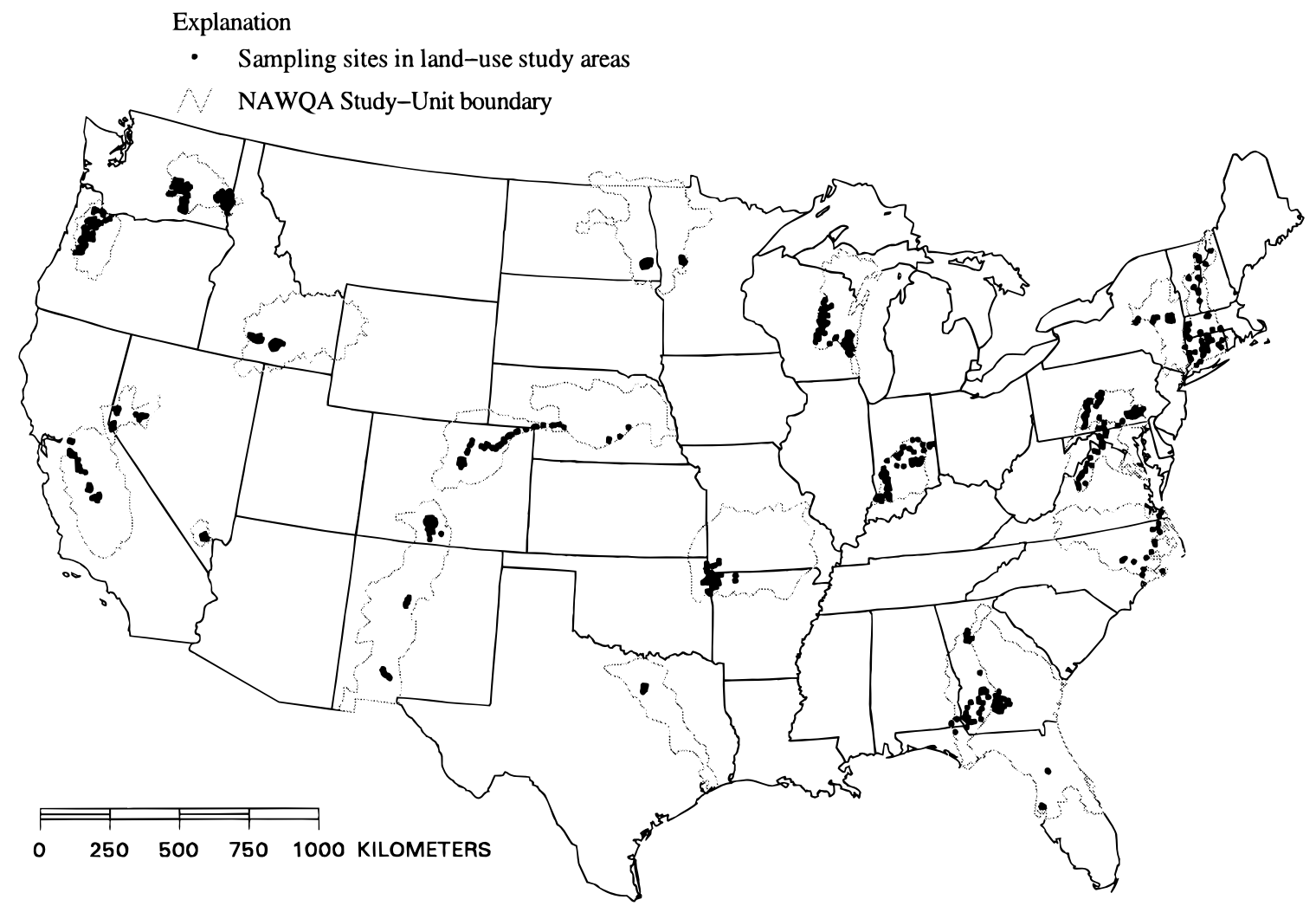

FIGURE 1. Locations of the 1034 sampling sites for the 41 land-use studies and the boundaries of the 20 NAW QA Study Units in which these studies were carried out.

total of 1012 wells and 22 springs (Figure 1 ) were sampled for 41 land-use studies from June 1993 to March 1995 (see ref 78 for details).

Sampling and Analytical Procedures. All samples were collected by U.S. Geological Survey (USGS) personnel using protocols and procedures designed to obtain a water sample representative of the targeted aquifer $(11,12)$. Before water samples were collected, each site was pumped until fieldmeasured values of $\mathrm{pH}$, water temperature, specific conductance, and dissolved oxygen concentration stabilized. After being passed through a $0.7-\mu \mathrm{m}$, baked, glass fiber filter to remove suspended particles, $1 \mathrm{~L}$ of sample was either (a) stored in an amber, baked glass bottle and immediately chilled before and during shipment to the laboratory or (b) pumped through a solid-phase extraction (SPE) cartridge, which was then chilled and shipped to the laboratory. The effectiveness of the sampling protocol and the analytical procedures used for this study was verified through the routine analysis of blank, replicate, and spiked samples for quality control (11).

In the laboratory, pesticide analytes were eluted from the SPE columns using a 3:1 hexane-2-propanol mixture. The resulting extracts were concentrated under a stream of nitrogen gas and analyzed for a total of 46 pesticide compounds -25 herbicides, 17 insecticides, 2 herbicide transformation products (degradates), and 2 insecticide degradates-using capillary column gas chromatography/ mass spectrometry (12). Although dieldrin-a discontinued insecticide-is classified as a parent compound in this paper (Table 1), it also can be derived from the in situ epoxidation of aldrin (16), another discontinued insecticide. Themethod detection limits (MDL) of the 46 pesticidecompounds varied from 0.001 to $0.018 \mu \mathrm{g} / \mathrm{L}$ (Table 1 ), but these are provided only to indicate relative analytical precision and detection sensitivity and were not used as a lower limit for reporting concentrations that otherwise met compound identification criteria (12). Concentration values for detections below the
MDL are designated as estimated values in the USGS database.

Land-Use Classification. I Information on cropping patterns provides a useful surrogate for agrichemical use and, to a certain extent, climatic, soil, and hydrogeologic characteristics (17). The 31 agricultural land-use studies were grouped into nine categories according to the principal crops grown within each area, based on a classification system developed for a national water-quality assessment (18).

Pesticide Use Data. To examine relations between the use and detection of pesticides in groundwater, data on pesticide applications (19) were assembled for each sampled area. For each pesticide, thetotal amount of activeingredient applied to agricultural crops and pasture was estimated for every county containing one or more of the 813 agricultural sampling sites. The intensity of use (mass applied per unit area) for each compound was then computed by dividing the total amount applied in the sampled counties by the total area of cropland in these counties, including orchards, vineyards, citrus groves, and pasture (20). Thepesticide use data do not include applications to fallow land or nonagricultural areas (e.g., rights of way, lawns, golf courses, or sod farms), and thus do not include data for any of the counties sampled for the 10 urban land-use studies.

Physical and Chemical Properties of Pesticides. Data on some of the physical and chemical properties of pesticides were used to examinetheir relationsto the detection of these compounds in groundwater. The four parameters that have been used most frequently for this purpose are $\mathrm{K}_{\mathrm{oc}}$, which describes the partitioning of organic compounds between water and soil organic carbon; Henry's law constant, which characterizes the partitioning between the aqueous and gas phases; water solubility, which provides an estimate of the maximum aqueous concentration likely to be encountered; and soil dissipation half-life, which serves as a rough indicator of persistencein situ. Values of $\mathrm{K}_{\mathrm{oc}}$, water solubility, and soil dissipation half-life were obtained from various sources (21- 
TABLE 1. Method Detection Limits, Detection Frequencies, Maximum Concentrations, and Drinking Water Quality Criteria for Pesticide Compounds Examined for This Investigation ${ }^{\mathrm{a}}$

\begin{tabular}{|c|c|c|c|c|c|c|c|c|c|c|c|c|c|c|c|}
\hline \multirow[b]{3}{*}{ compd } & \multirow[b]{3}{*}{$\begin{array}{c}\text { MDL } \\
(\mu \mathrm{g} / \mathrm{L})\end{array}$} & \multicolumn{12}{|c|}{ frequency of detection (percent of sites) } & \multirow[b]{3}{*}{$\begin{array}{l}\max _{\text {concn }} \\
(\mu \mathrm{g} / \mathrm{L})\end{array}$} & \multirow{3}{*}{$\begin{array}{c}M C L \\
H A, \text { or } \\
R S D(\mu \mathrm{g} / \mathrm{L})\end{array}$} \\
\hline & & \multirow{2}{*}{$\begin{array}{c}\text { field } \\
\text { blanks } \\
\text { (15) }\end{array}$} & \multirow[b]{2}{*}{ all } & \multicolumn{10}{|c|}{ land-use settings } & & \\
\hline & & & & $\begin{array}{l}\& \& 5 \\
>20\end{array}$ & $\begin{array}{l}c \& a \\
>20\end{array}$ & $\begin{array}{l}\text { Corn } \\
>50\end{array}$ & $\begin{array}{c}\text { peanuts } \\
>50\end{array}$ & $\begin{array}{c}\text { wheat } \\
>50\end{array}$ & $\begin{array}{c}\text { w\&a } \\
>20\end{array}$ & $\begin{array}{l}\text { alf } \\
>50\end{array}$ & pasture & $\begin{array}{l}\text { orch/ } \\
\text { vine }\end{array}$ & urban & & \\
\hline \multicolumn{16}{|c|}{ Herbicides } \\
\hline alachlor & 0.002 & 0.0 & 2.4 & 6.6 & 1.7 & 12.3 & 8.2 & 1.2 & 1.8 & 0.0 & 0.0 & 0.0 & 0.0 & 0.55 & 2 \\
\hline atrazine & 0.001 & 2.8 & 38.2 & 19.7 & 78.2 & 55.4 & 9.8 & 60.4 & 24.1 & 0.0 & 17.9 & 25.0 & 18.6 & 3.60 & 3 \\
\hline benfluralin & 0.002 & 1.4 & 0.1 & 0.0 & 0.4 & 0.0 & 0.0 & 0.0 & 0.0 & 0.0 & 0.0 & 0.0 & 0.0 & 0.004 & - \\
\hline butylate & 0.002 & 0.0 & 0.2 & 0.0 & 0.0 & 1.5 & 0.0 & 0.0 & 0.0 & 0.0 & 0.0 & 1.7 & 0.0 & 0.002 & 350 \\
\hline cyanazine & 0.004 & 0.0 & 1.6 & 0.0 & 4.2 & 4.6 & 0.0 & 0.0 & 0.0 & 0.0 & 0.0 & 1.7 & 1.4 & 0.52 & 1 \\
\hline DCPA & 0.002 & 0.7 & 0.8 & 0.0 & 2.1 & 0.0 & 0.0 & 0.0 & 0.6 & 0.0 & 0.0 & 3.3 & 0.0 & 10.0 & - \\
\hline EPTC & 0.002 & 0.0 & 1.5 & 0.0 & 3.3 & 4.6 & 0.0 & 1.2 & 1.8 & 0.0 & 0.0 & 1.7 & 0.0 & 0.45 & - \\
\hline ethalfluralin & 0.004 & 0.0 & 0.3 & 0.0 & 0.4 & 0.0 & 0.0 & 0.0 & 0.6 & 0.0 & 0.0 & 1.7 & 0.0 & 0.09 & - \\
\hline & 0.002 & 0.0 & 0.3 & 0.0 & 0.0 & 1.5 & 0.0 & 2.3 & 0.0 & 0.0 & 0.0 & 0. & 0.0 & 0.029 & - \\
\hline olachlor & 0.002 & 1.4 & 14.6 & 21.3 & 27.6 & 41.5 & 26.2 & 9.3 & 3.7 & 22.5 & 0.0 & 3.3 & 1.8 & 5.40 & 100 \\
\hline netribuzin & 0.004 & 0.0 & 3.1 & 6.6 & 2.1 & 0.0 & 1.6 & 9.3 & 6.2 & 0.0 & 0.0 & 0.0 & 1.8 & & 100 \\
\hline & 0.004 & 0.0 & 0.0 & 0.0 & 0.0 & 0.0 & 0.0 & 0.0 & 0.0 & 0.0 & 0.0 & 0. & 0.0 & 0.0 & - \\
\hline opamide & 0.003 & 0.0 & 0.2 & 0.0 & 0.4 & 0.0 & 0.0 & 0.0 & 0.0 & 2.5 & 0.0 & 0.0 & 0.0 & 0.014 & - \\
\hline pebulate & 0.004 & 0.0 & 0.4 & 0.0 & 0.4 & 3.1 & 0. & 1.2 & 0.0 & 0.0 & 0.0 & & 0.0 & 52 & - \\
\hline imethalin & 0.004 & 0.0 & 0.2 & 0.0 & 0.4 & 1.5 & 0.0 & 0.0 & 0.0 & 0.0 & $0 .($ & 0.0 & 0.0 & 0.012 & - \\
\hline eton & 0.018 & 0.7 & 13.9 & 0.0 & 20.1 & 38.5 & 0.0 & 7.0 & 1.2 & 12.5 & 5.1 & 1.7 & 24.9 & 40.0 & 100 \\
\hline amide & 0.003 & 0.7 & 0.1 & 1.6 & 0.0 & 0.0 & & 0. & 0.0 & 0.0 & & & 0.0 & & 50 \\
\hline chlor & 0.007 & 0.0 & 0.3 & 0.0 & 0.0 & 0.0 & $0 .(1-x-1)$ & 2.3 & 0.6 & 0.0 & 0.0 & 0.0 & 0.0 & 0.004 & 90 \\
\hline propanil & 0.004 & 0.7 & 0.7 & 0.0 & 0.0 & 0.0 & 0.0 & 4.6 & 1.2 & 0.0 & 0.0 & 0.0 & 0.4 & 0.015 & - \\
\hline zine & 0.005 & 1.4 & 18.0 & 1.6 & 28.0 & 26.2 & & 43.0 & 11.1 & 5.0 & & 31.7 & 10.0 & & 4 \\
\hline iuron & 0.010 & 0.0 & 2.2 & 0.0 & 3.8 & 4.6 & 0. & 0. & 0.0 & 0.0 & 2. & 0. & 5 & & 500 \\
\hline & 0.007 & 0.0 & 0.9 & 0.0 & 1.7 & 0.0 & 0. & 3. & 0.0 & 0.0 & 0. & & 4 & & 90 \\
\hline carb & 0.002 & 0.0 & 0.1 & 0.0 & 0.0 & 0.0 & & & & 0.0 & & 0. & 0 & & - \\
\hline & 0.001 & 1.4 & 0.5 & 0.0 & 1.2 & 0.0 & 0.0 & 0.8 & 1.2 & 0.0 & 0.0 & 0.0 & 0.0 & 02 & - \\
\hline trifluralin & 0.002 & 0.7 & 0.5 & 0.0 & 0.8 & 0.0 & 0.0 & 0.0 & 0.0 & 0.0 & 0.0 & 3.3 & 0.4 & 0.014 & 5 \\
\hline \multicolumn{16}{|c|}{ Insecticides } \\
\hline azinphos-methyl & 0.001 & 0.0 & 0.0 & 0.0 & 0.0 & 0.0 & 0.0 & 0.0 & 0.0 & 0.0 & 0.0 & 0.0 & 0.0 & - & - \\
\hline carbaryl & 0.003 & 0.0 & 1.1 & 0.0 & 0.4 & 0.0 & 0.0 & $5 . \varepsilon$ & 0.0 & 0.0 & 0.0 & 1.7 & 1.8 & 0.021 & 700 \\
\hline ran & 0.003 & 0.0 & 0.7 & 1.6 & 2.1 & 0.0 & & & & 0.0 & & & & & 40 \\
\hline ifos & 0.004 & 1.4 & 0.2 & 1.6 & 0.0 & 0.0 & 0.0 & 0.0 & 0.0 & 0.0 & 0.0 & 1.7 & 0.0 & 0.006 & 20 \\
\hline & 0.002 & 0.7 & 0.7 & 3.3 & 0.8 & 0.0 & 0.0 & 0.0 & 0.0 & 2.5 & 0.0 & 0.0 & 0.9 & 0.077 & 0.6 \\
\hline ild & 0.001 & 0.0 & 1.4 & 0.0 & 0.8 & 1.5 & & & & 0.0 & & & & 0.0 & 0.002 \\
\hline oton & 0.017 & 0.0 & 0.0 & 0.0 & 0.0 & 0.0 & 0.0 & 0. & 0.0 & 0.0 & 0.0 & 0.0 & 0.0 & - & 0.3 \\
\hline & 0.003 & 0.0 & 0.1 & 0.0 & 0.0 & 0.0 & 0.0 & 0.8 & 0.0 & 0.0 & 0.0 & & 0.0 & 0.009 & - \\
\hline & 0.00 & 0.0 & 0.1 & 0. & 0.0 & 0.0 & & 0. & & 0.0 & & & & 0.009 & 10 \\
\hline$(\gamma-\mathrm{HCH})$ & 0.004 & 0.0 & 0.0 & 0.0 & 0.0 & 0.0 & 0. & 0.0 & 0.0 & 0.0 & 0.0 & 0.0 & 0.0 & - & 0.2 \\
\hline Malathic & 0.005 & 0.0 & 0.2 & 0.0 & 0.4 & 0.0 & 0. & $0 .($ & 0.0 & 0.0 & 0.0 & & 0.0 & 0.004 & 200 \\
\hline -ethyl & 0.004 & 0.0 & 0.0 & 0.0 & 0.0 & 0.0 & & 0. & 0. & 0.0 & 0. & & 0 & - & - \\
\hline parathion-methyl & 0.006 & 0.0 & 0.0 & 0.0 & 0.0 & 0.0 & 0. & $0 .($ & 0.0 & 0.0 & 0.0 & 0.0 & 0.0 & - & 2 \\
\hline cis-permethrin & 0.005 & 0.7 & 0.2 & 0.0 & 0.8 & 0.0 & 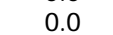 & 0.0 & 0.0 & 0.0 & 0.0 & 0.0 & 0.0 & 0.007 & - \\
\hline & 0.002 & 0.0 & 0.0 & 0.0 & 0.0 & 0.0 & 0.0 & 0.8 r & 0.0 & 0.0 & 0.0 & & 0.0 & - & - \\
\hline propargite & 0.013 & 0.0 & 0.1 & 0.0 & 0.4 & 0.0 & 0.0 & 0.0 & 0.0 & 0.0 & 0.0 & 0.0 & 0.0 & 0.009 & - \\
\hline terbufos & 0.013 & 0.0 & 0.1 & 0.0 & 0.0 & 0.0 & 0.0 & 0.0 & 0.6 & 0.0 & 0.0 & 0.0 & 0.0 & 0.008 & 0.9 \\
\hline \multicolumn{16}{|c|}{ Degradation Products } \\
\hline$p$-DDE & 0.006 & 4.1 & 3.9 & 0.0 & 6.3 & 6.2 & 0.0 & 7.0 & 3.1 & 2.5 & 5.1 & 1.7 & 2. & 0.006 & 0.1 \\
\hline & 0.002 & 0.7 & 34.2 & 9.8 & 77.0 & 53.8 & 6.6 & 40.7 & 21.6 & 0.0 & 17.9 & 26.7 & 14.5 & & - \\
\hline 2,6-diethylaniline & 0.003 & 0.0 & 1.9 & 8.2 & 0.8 & 1.5 & 0.0 & 10.5 & 1.8 & 0.0 & 0.0 & 0.0 & 0.0 & 0.085 & - \\
\hline \multirow{2}{*}{$\begin{array}{l}\alpha-\mathrm{HCH} \\
\text { no. of sites sample }\end{array}$} & 0.002 & 0.0 & 0.1 & 0.0 & 0.0 & 0.0 & 0.0 & 0.0 & 0.6 & 0.0 & 0.0 & 0.0 & 0.0 & 0.059 & - \\
\hline & & 145 & 1034 & 61 & 239 & 65 & 61 & 87 & 161 & 40 & 39 & 60 & 221 & & \\
\hline
\end{tabular}

a MDL, method detection limit; $c \& s>20$, corn and soybeans $>20 \%$; $c \& a>20$, corn and alfalfa $>20 \%$; corn $>50$, corn $>50 \%$; wheat $>50$, wheat and small grains $>50 \%$; w\&a $>20$, wheat and small grains and alfalfa $>20 \%$; alf $>50$, alfalfa $>50 \%$; pasture, pasture $>90 \%$; orch/vine, orchards or vineyards > 50\%; max concn, maximum concentration; $\mathrm{MCL}$, maximum contaminant limit (13); HA, health advisory level (13), shown in boldface in table; RSD, risk-specific dose (RSD) associated with a risk of one additional person in one million contracting cancer over a 70-year lifespan (14), shown in italics in table; -, no standard available. ${ }^{b}$ Also could have been formed from the degradation of the insecticide aldrin.

26), while Henry's law constants were taken from the summary by Suntio et al. (27). Most literature values for soil dissipation half-life represent some unknown combination of the influences of transformation and off-site transport in reducing theconcentration of a given compound at the point of measurement (3). Despite these uncertainties, the soil dissipation half-life was used as an approximate measure of persistence-instead of actual rate constants for transformation-because of the more widespread use and availability of this parameter.

Detection Frequencies. The detection frequencies for the pesticidecompounds under investigation werecalculated in two different ways, i.e., unadjusted, based on all detections regardless of concentration (Table 1 ), and adjusted, based on a common detection threshold for all compounds (Figure 2). The use of unadjusted detection frequencies maximizes the ability to track the movement and fate of individual pesticides in the environment because every detection is included, with no loss of information. The unadjusted method, however, is inappropriatefor comparing occurrence data among pesticide compounds with varying detection thresholds because frequencies of pesticide detection are inversely related to analytical reporting limits $(3,28)$. The adjusted method applied a common detection threshold of $0.01 \mu \mathrm{g} / \mathrm{L}$ for computing detection frequencies, thus facilitating unbiased comparisons among compounds. 


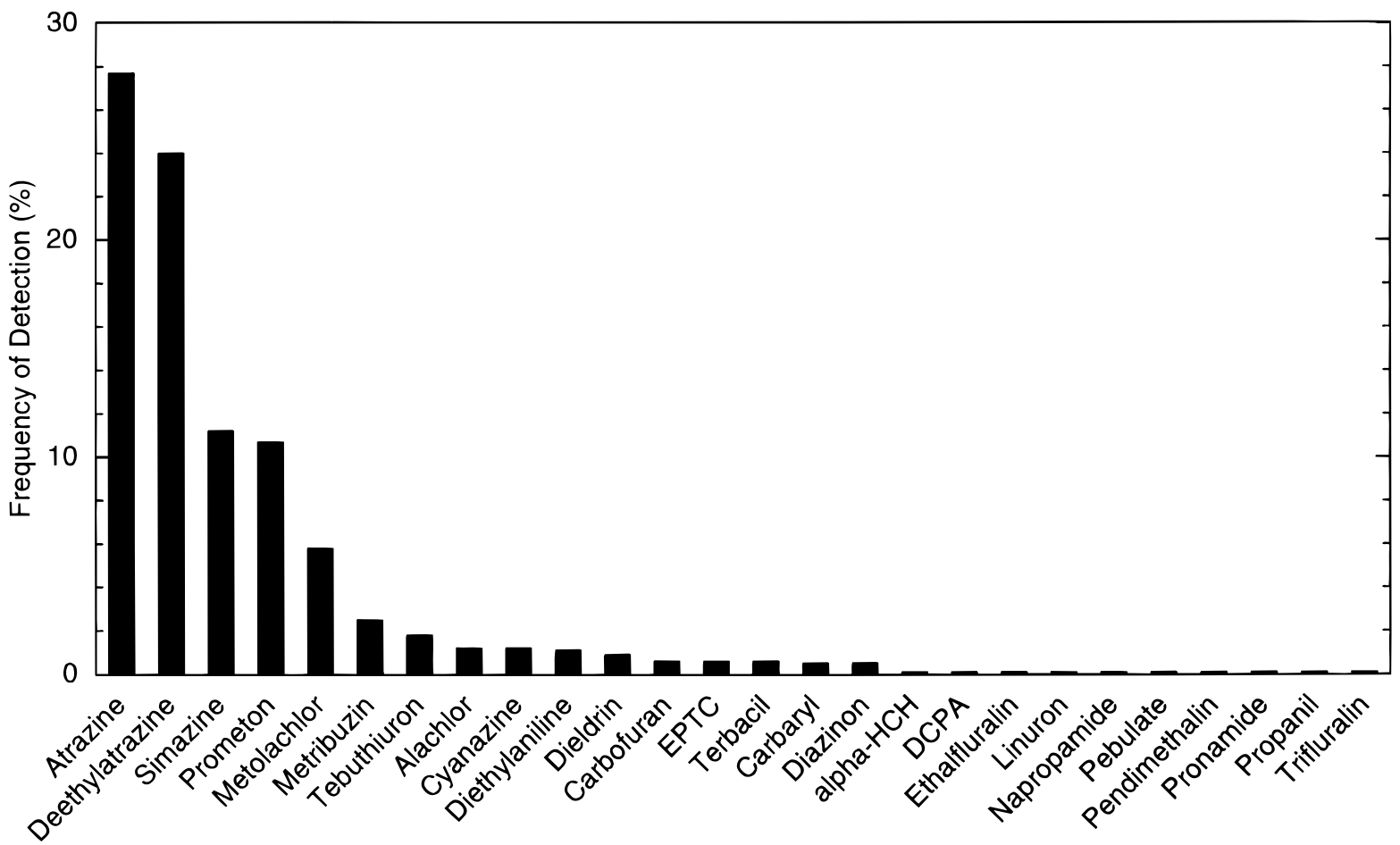

FIGURE 2. Frequencies of detection of pesticide compounds in shallow groundw ater during the 41 land-use studies, adjusted to a common detection threshold of $0.01 \mu \mathrm{g} / \mathrm{L}$.

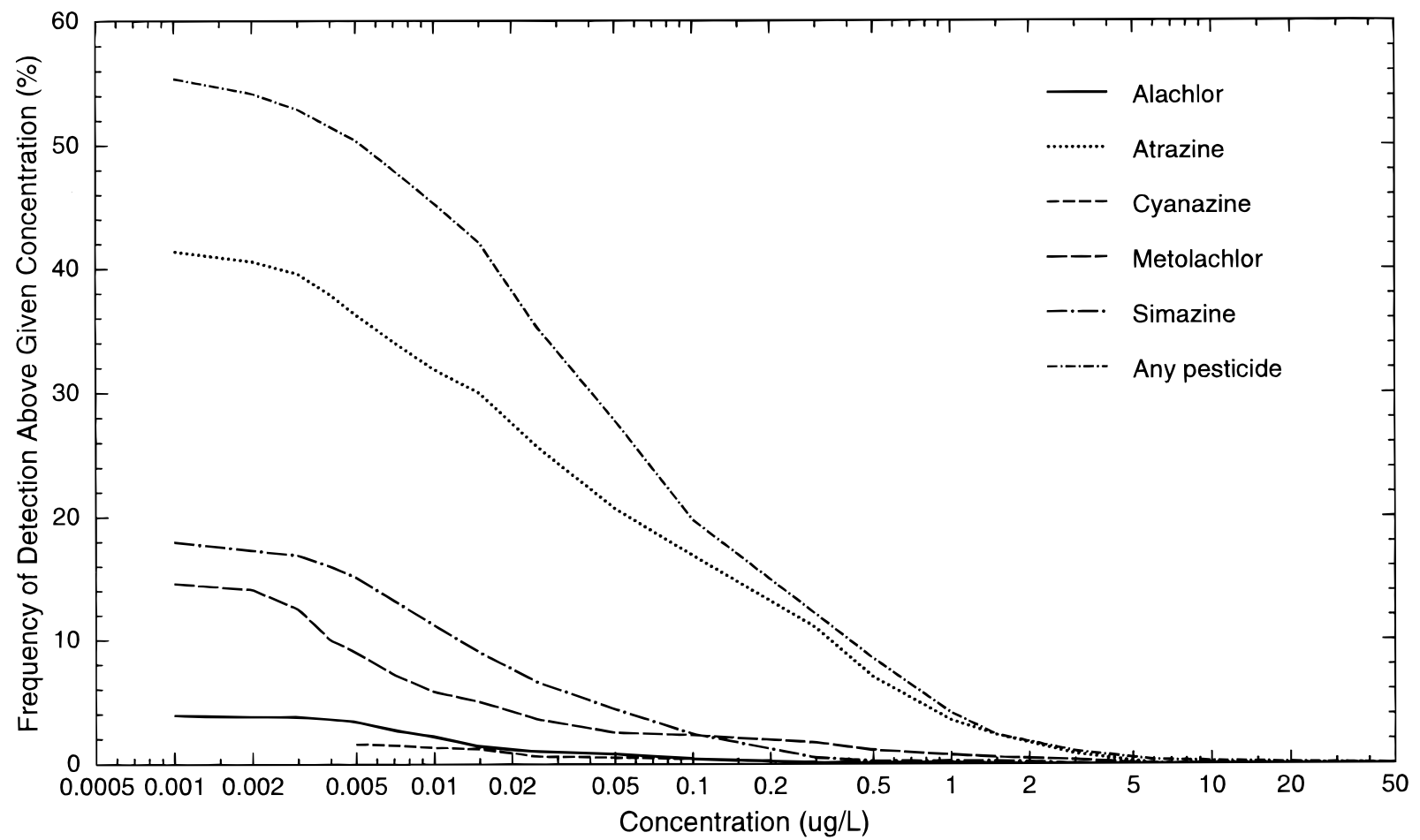

FIGURE 3. Frequencies of detection of selected pesticides in relation to detection threshold for shallow groundwater sampled in 41 land-use studies. The line for "any pesticide" represents the frequencies $w$ ith $w$ hich the sum of all pesticide compound concentrations in individual samples exceeded the given concentration (concentrations of compounds that were not detected were set to zero).

\section{Results and Discussion}

Overall Frequencies of Pesticide Detection and Comparisons with Previous Multistate Studies. Detections of pesticide compounds were widespread in the shallow groundwater sampled, with one or more pesticide compounds being detected in $54.4 \%$ of the 1034 wells and springs sampled. Thirty-nine different pesticide compounds were detected (Table 1), 26 of which had at least oneconcentration above $0.01 \mu \mathrm{g} / \mathrm{L}$ (Figure 2). Consistent with findings from previous multistate studies (29), more than $95 \%$ of the reported pesticide concentrations were less than $1.0 \mu \mathrm{g} / \mathrm{L}$ (Figure 3). With the exception of DDE, the results for the field blanks support the reliability of the pesticide data collected for this study (Table 1 ). The relatively frequent detections of DDE in the field blanks as compared to environmental samples will be examined in more detail to 
determine whether any of the DDE detections in the groundwater samples arose from either sampling or laboratory procedures.

Herbicides were detected in shallow groundwater much morefrequently $(52.4 \%)$ than were insecticides $(7.5 \%)$. This pattern is consistent with early results reported by individual NAWQA StudyUnits (e.g., refs 30-32) and may bea reflection of the fact that herbicides are used in much greater quantities than insecticides (e.g., ref 33). Other factors, such as the persistence of the different compounds in situ or their method and timing of application, also may be important in contributing to the greater frequency of herbicide detection for this study relative to the insecticides.

The overall frequency of pesticide detection for the 41 land-use studies is considerably higher than those reported by two previous large-scale, multistate studies of pesticide occurrence in groundwater across the United States. Estimates from the National Pesticide Survey (NPS) indicated that one or more pesticides were likely to be detected in the water from $10.4 \%$ of the public supply and $4.2 \%$ of the domestic wells in the nation from 1988 to 1990 (34). The National Alachlor Well Water Survey (NAWWS) projected that, during the period from 1987 to 1989 , one or more herbicides were likely to be detected in water obtained from $12 \%$ of the estimated 6 million existing domestic wells in counties in the United States where alachlor was sold (35).

The contrasts in pesticide detection frequencies between this study and the NPS and NAWWS investigations are attributable primarily to (a) low detection threshold characteristics of the analytical method used for NAWQA and (b) the relatively young age of groundwater sampled in the NAWQAland-usestudies. Frequencies of pesticidedetection are inversely related to the detection threshold (Figure 3). For example, the NAWQA detection threshold for atrazine in Figure 2 is $0.01 \mu \mathrm{g} / \mathrm{L}$, whereas the reporting limits for the NAWWS and NPS studies were 0.03 and $0.12 \mu \mathrm{g} / \mathrm{L}$, respectively. The frequencies of atrazine detection for the three studies decreased in the same order that the detection thresholdsincreased-27.7\%(Figure 2), $11.68 \%$ (35), and $0.7 \%$ (34). Censoring the NAWQA atrazine data to the NPS and NAWWS reporting limits substantially decreases the atrazine detection frequency, but not to values as low as those for either the NPS or NAWWS investigations (Figure 3). A likely contributor to the remaining difference is that NAWQA landuse studies focus on sampling only shallow, recently recharged groundwater, while the NPS and NAWWS studies sampled groundwater from existing wells, tapping groundwater with considerably broader ranges in age. Previous research has shown that "younger" groundwater is more likely to contain pesticides at detectable concentrations than "older" waters $(28,36)$.

Relations to Pesticide Use. Once variations in detection thresholds among the pesticide compounds have been accounted for (Figure 2), the reasons underlying the differences in frequencies of detection among the compounds can be examined. Previous work has demonstrated that variations in pesticide use are likely to affect the occurrence of pesticide compounds in groundwater $(3,37)$. Since only limited data on nonagricultural use areavailable, theanalysis of relations between occurrence and use was restricted to parent compounds with substantial present-day agricultural use and thus excluded pesticides used primarily for nonagricultural purposes (prometon and tebuthiuron) or those that have been discontinued (dieldrin). Because of thefocus on agricultural pesticides, the analysis was further limited to the data from theagricultural land-usestudies. The pesticide use estimates employed in the correlation analysis are of total use in all counties included in the agricultural land-use studies. Consistent with expectation, a significant, positive relation was indeed observed between frequencies of detec- tion (Figure 2) and estimated use $(r=0.36 ; p=0.02$; Spearman rankcorrelation). Although significant, the weak correlation indicates that other factors also need to be considered to moreaccurately account for variations in pesticidedetections in groundwater. Had it been available, specific information on chemical use within the vicinity of the sampled wells-rather than the estimated use throughout the surrounding counties-may have yielded a stronger relation between chemical use and pesticide detection frequencies in groundwater for this study. U sing the estimated use for each land-use study (discussed later in this paper) rather than the total in all counties may also improve the relation between chemical use and pesticide detection frequencies.

Relations to Pesticide Properties. Differences in subsurface mobility and persistence among different pesticides are commonly thought to contribute to variations in their frequencies of detection in groundwater. Consequently, data on the physical and chemical properties of pesticides have often been used to predict the likelihood of their reaching groundwater in detectable concentrations (3).

Frequencies of pesticide detection exhibited a significant, inverse correlation with $\mathrm{K}_{\mathrm{oc}}$ values $(r=-0.57, \mathrm{p}<0.001$; Spearman rank correlation) and a significant, positive correlation with water solubility $(r=0.39, p=0.01$; Spearman rank correlation), but correlations with soil dissipation halflife $(p=0.12)$ and Henry's law constant $(p=0.06)$ were not significant at $\alpha=0.05$. The significant correlations with $\mathrm{K}_{\mathrm{oc}}$ and water solubility are in agreement with the anticipated effects of these parameters on pesticide detections in groundwater. Furthermore, the observation of a stronger correlation of detection frequency with $\mathrm{K}_{\mathrm{oc}}$ than with water solubility is consistent with the fact that the value of $\mathrm{K}_{\mathrm{oc}}$ reflects the effects of soil organic matter on pesticidetransport in the subsurface, while the use of water solubilities does not (3). The absence of a significant correlation between detection frequency and Henry's law constant is consistent with the comparatively low volatility of the pesticide compounds examined. The lack of a significant correlation with dissipation half-life is somewhat unexpected but may bedue to (a) the variable manner in which this parameter has been determined, (b) the fact that it represents some unknown combination of transformation and off-sitetransport (3), and (c) the limited range of dissipation half-live values exhibited by the compounds evaluated.

Improvements in explaining the frequencies of pesticide detection determined from this study are obtained by using a multivariate approach, taking information on both estimated useand physical properties into account. All variables were log-transformed for this analysis, which resulted in relatively normal distributions. The resulting correlation matrix for the transformed data indicated pairwise correlations that were similar to those observed from the rank correlation analysis. The amount of variance in the logtransformed frequencies of pesticide detection that was explained by these parameters was found to be $18 \%$ for estimated usealone $\left(p=0.007 ; R^{2}=0.18\right), 48 \%$ for estimated use $+K_{o c}\left(p<0.001\right.$ for $\left.K_{o c} ; R^{2}=0.48\right)$, and $52 \%$ for estimated use $+K_{o c}+$ soil dissipation half-life $(p=0.10$ for soil dissipation half-life; $\mathrm{R}^{2}=0.52$ ). Thus, consistent with the pairwise analysis, dissipation half-life accounted for only a limited amount of the variation in pesticide detection frequency. Neither water solubility nor Henry'slaw constants could be included in this multivariate regression analysis because both were significantly correlated with $\mathrm{K}_{\text {oc. }}$. Thus, among the parameters considered, estimated use and $\mathrm{K}_{\mathrm{oc}}$ have the most profound effect on determining pesticide occurrence in groundwater.

Following an approach analogous to that described by Baker et al. (38) for assessing groundwater vulnerability to pesticide contamination, each compound examined for the 


\section{EXPLANATION}

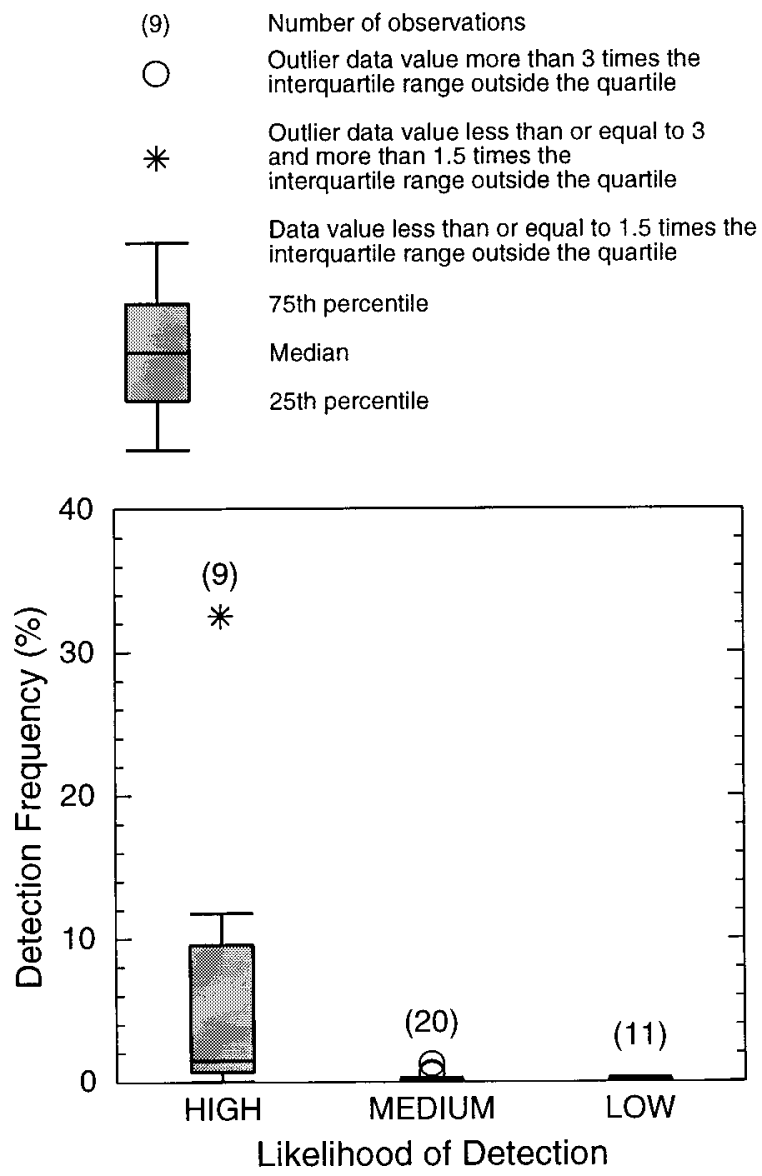

FIGURE 4. Frequencies of detection (\%) of pesticides detected $\geq 0.01 \mu \mathrm{g} / \mathrm{L}$ in relation to agricultural use and $K_{\text {oc }}$. Pesticides with high likelihood of detection had both high use $\left(\geq 1.00 \mathrm{~kg} / \mathrm{km}^{2}\right)$ and low $K_{\text {oc }}(<300 \mathrm{~mL} / \mathrm{g})$; those with low likelihood had both low use $\left(<1.00 \mathrm{~kg} / \mathrm{km}^{2}\right)$ and high $K_{0 c}(\geq 300 \mathrm{~mL} / \mathrm{g}) ;$ those with medium likelihood had either high use and high $K_{o c}$ or low use and low $K_{o c}$. Number of pesticides in each category is given in parentheses.

multivariate analysis was classified as having either a high, medium, or low likelihood of being detected in groundwater, based on specific threshold values for use $(1.00 \mathrm{~kg} /$ $\mathrm{km}^{2}$-roughly the median intensity of use among these compounds) and $\mathrm{K}_{\mathrm{oc}}(300 \mathrm{~mL} / \mathrm{g}$ (39)). This approach demonstrates that, as anticipated, the frequencies of detection of different compounds generally diminished as the "likelihood of detection" decreased (Figure 4).

Variations in Pesticide Detection Frequencies among Land-Use Categories. Ten land-use categories were used for this study: corn and soybeans each $>20 \%$ (corn and soybeans $>20$ ); corn and alfalfa each $>20 \%$ (corn and alfalfa $>20$ ); corn $>50 \%$ (corn $>50$ ); peanuts $>50 \%$ (peanuts $>50$ ); wheat and small grains $>50 \%$ (wheat $>50$ ); wheat and small grains and alfalfa each $>20 \%$ (wheat and alfalfa $>20$ ); alfalfa $>50 \%$ (alfalfa $>50$ ); pasture $>90 \%$ (pasture); orchards or vineyards $>50 \%$ (orchard/vineyard $>50$ ); and urban areas (urban).

Pesticide compounds were commonly detected in both agricultural (56.4\%; 813 sites) and urban (46.6\%; 221 sites) settings. Frequent detections of pesticides in urban areas indicate that, as is the case for agricultural pesticide use in agricultural areas, urban and suburban pesticide use also significantly contribute to pesticide occurrence in shallow

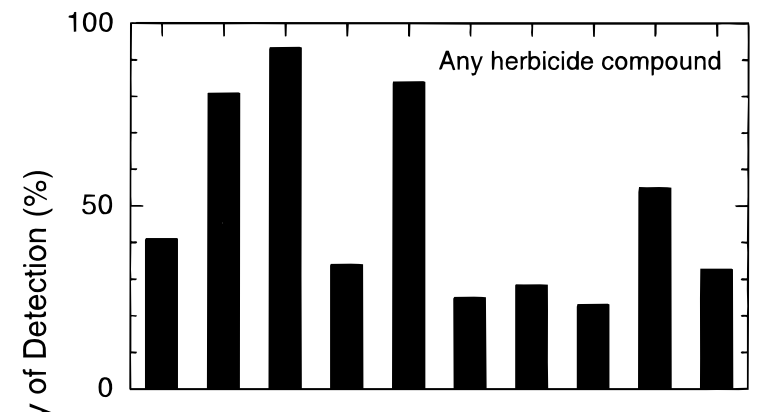

을

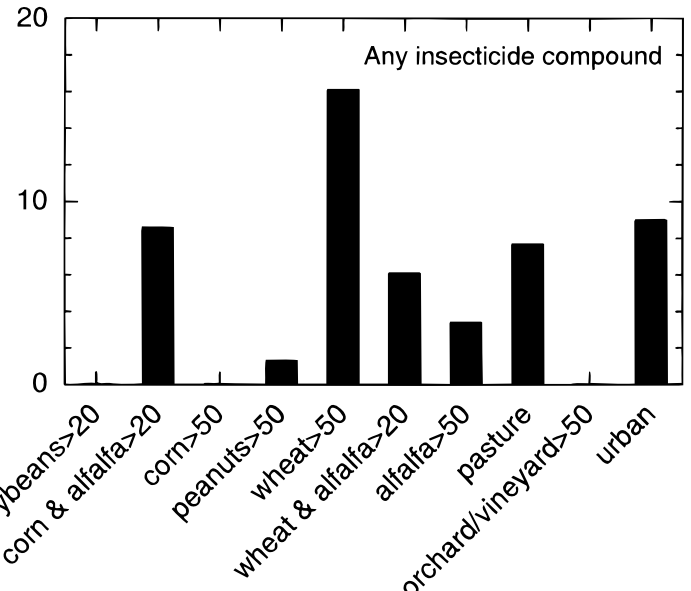

FIGURE 5. Frequencies of herbicide and insecticide detection in shallow groundwater beneath 10 different land-use settings.

groundwater. Although pesticides were detected in groundwater sampled in all 10 of the land-use study categories, significant variations were observed in the frequencies of herbicide and insecticide detection among these categories (Table1; Figure 5). For example, although the urban category ranked seventh in its median frequency of herbicide detection, it ranked second in its median frequency of insecticide detection (Figure5). Similar contrasts in insecticidedetection frequencies between agricultural and urban areas have also been observed in streams $(40,41)$.

Considerable variations also were observed in the assemblages of pesticide compounds most frequently detected in each of the land-use categories (Figure 6). Because the patterns of chemical use differ among these categories, these variations are not unexpected. Indeed, some of the variation in occurrence for a particular compound among the landuse categories can be explained by differences in theintensity of use. Statistically significant relations ( $p<0.05$; Spearman's rank correlation) between overall frequencies of detection (Table 1) and the intensity of chemical use among different agricultural land-use studies were observed for six of the pesticides detected: atrazine residue (atrazine or deethylatrazine; $r=0.402, p=0.025)$, cyanazine $(r=0.435, p=$ 0.014), DCPA ( $r=0.426, p=0.017)$, metolachlor $(r=0.742$, $p<0.001)$, metribuzin $(r=0.361, p=0.046)$, and pendimethalin $(r=0.412, p=0.021)$.

Atrazineresidues were detected more frequentlythan any other pesticidecompounds during thisstudy (Table 1, Figure 2 ), with occurrences in nine of the 10 land-use categories (Figure 6). The widespread detections of atrazine residues in groundwater are likely to have been the combined result of the comparatively slow rate of atrazine transformation under environmental conditions (42-44) and the extensive, long-term use of the herbicide in both agricultural and nonagricultural settings in this country (45). Indeed, atrazine has been the pesticide used most extensively in the United States since the early 1970 s $(46,47)$ and has been the parent 

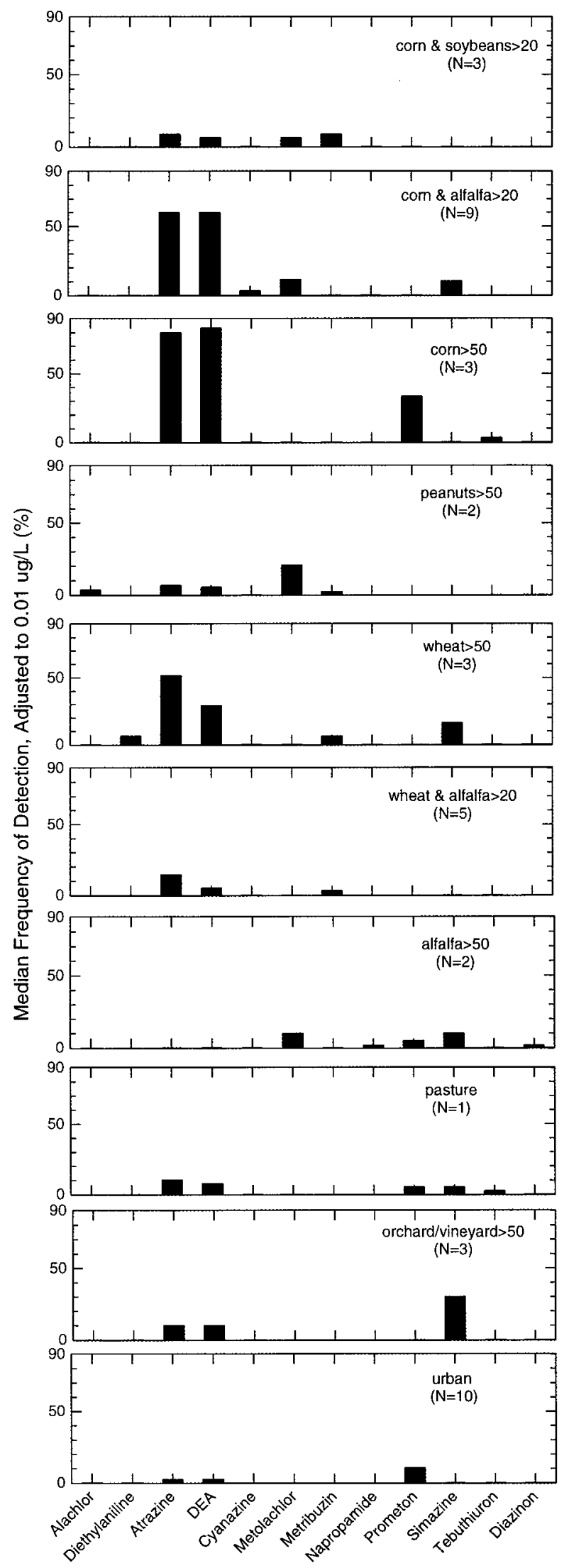

FIGURE 6. Frequencies of detection ( $\geq 0.01 \mu \mathrm{g} / \mathrm{L}$ ) of individual pesticides in shallow groundwater beneath 10 different land-use settings ( $N=$ number of land-use studies in each category).

compound detected most frequently in groundwater during many previous regional $(34,35,48)$, statewide $(49-51)$, and
NAWQA studies (32,52-54). Astatistically significant relation between the intensity of agricultural atrazine use and the frequency of atrazine residue detection in groundwater among different agricultural land-use studies was observed (Figure 7).

The relation shown in Figure 7 mimics those commonly observed between pesticide detection frequencies and pesticideuse, wherein relatively infrequent detections occur at low use, but a broad range of detection frequencies are encountered at higher use (3). Intensive pesticide use thus appears to be a necessary but not a sufficient condition for encountering high frequencies of pesticide detection in groundwater. The wider ranges in pesticide detection frequencies observed at higher use are presumed to reflect the varying influence of other factors in addition to use in governing pesticide detection rates among different areas (e.g., soil properties, hydrogeology, and recharge rates).

The clustering that is displayed among land-use studies conducted in similar agricultural settings (Figure 7) is likely to have arisen from similarities in one or more of these environmental factors among thestudy areas of interest. For example, the comparatively low frequencies of atrazine residue detection in the corn and soybean $>20$ category (Figure 7) may be attributable to hydrogeologic factors such as low soil permeability and high soil organic matter content in the areas studied. Conversely, the two land-use studies in the wheat $>50$ category that exhibited unexpectedly high atrazine residue detection frequencies were noted to have permeable soils and intensiveirrigation-two factors known to facilitate the movement of pesticides to groundwater (5558).

In addition to atrazine, several other pesticidecompounds also merit some discussion. Prometon is used primarily for nonagricultural purposes; such as domestic and commercial applications to driveways, fence lines, lawns, and gardens and as an asphalt additive (59-61). Prometon was detected in eight of the 10 land-use categories-most frequently in the urban setting (Table 1)-and was the third most frequently detected parent compound for thisstudy (Figure2). Relations to chemical use could not be examined because no nationwide compilations of prometon use are currently available. Consistent with its predominantly nonagricultural use, however, the frequency of prometon detection was significantly related to the median percentage of urban land within $1 \mathrm{~km}$ of the sampled sites for each land-use study $(p=0.042$; Spearman rank correlation). Previous research has also documented a direct relation between urban-residential land useand prometon detections in groundwater $(62,63)$ as well as in surface water (41).

Dieldrin (a degradate of aldrin as well as an insecticide itself) is an organochlorine insecticide that was detected in groundwater duringthisstudy (Table1, Figure2), even though both dieldrin and aldrin have been banned from normal agricultural use in the United States since the mid-1970s (dieldrin was canceled for termiticidal use in 1987). While the concentrations and detection frequencies for dieldrin were quite low by comparison with many of the other pesticide compounds under investigation, the potential of this compound to accumulate to levels toxic to humans and aquatic life is much greater (64). As has been observed by other studies (e.g., refs 65-67), organochlorine insecticides continue to exert a negative impact on groundwater quality decades after having been banned from normal use.

\section{Significance to Human and Environmental Health}

Pesticides were commonly detected in shallow groundwater for this study, but their concentrations rarely exceeded current drinking water criteria established by the U.S. EPA for the protection of human health (Table 1). The concentration of atrazine exceeded its maximum contaminant level 


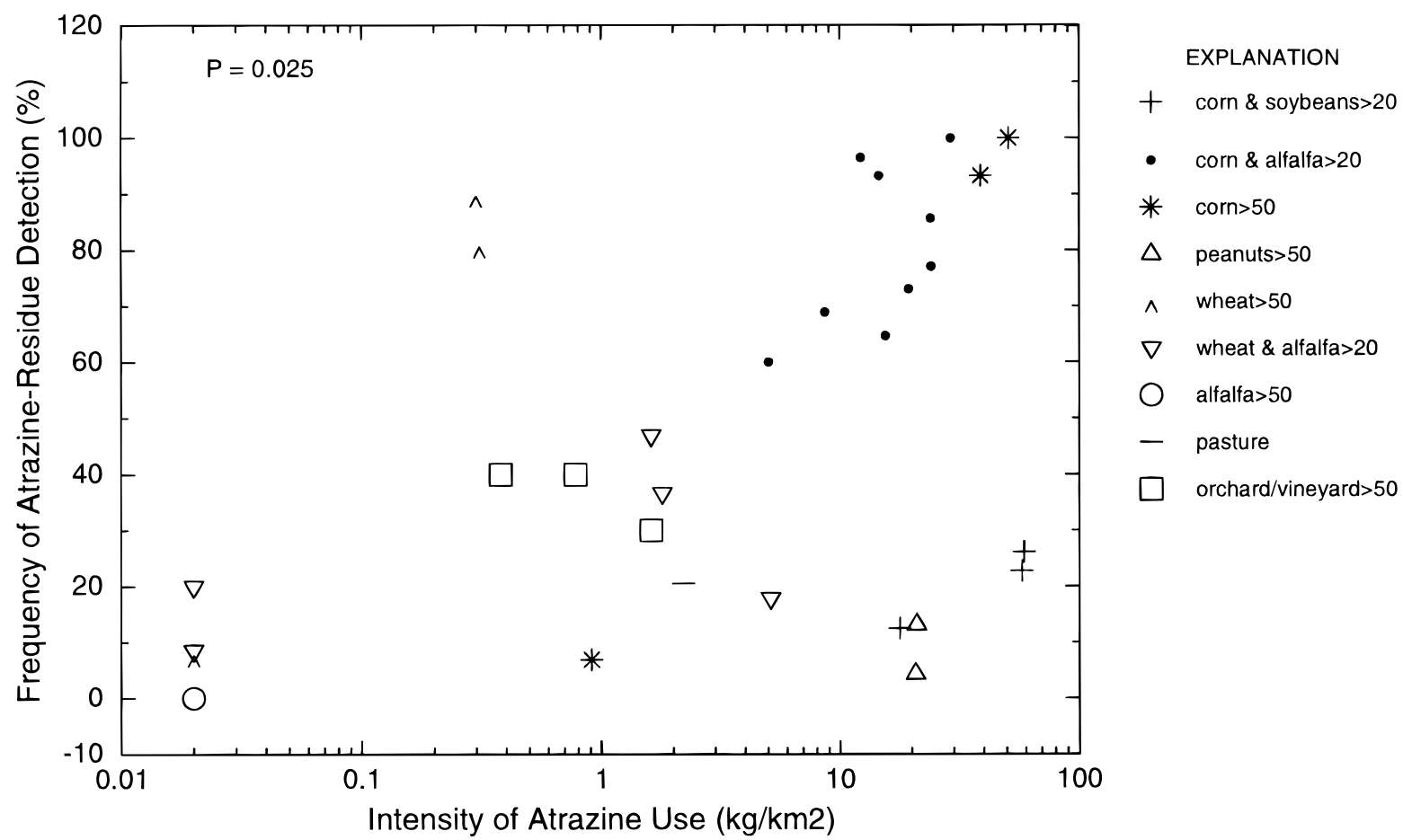

FIGURE 7. Frequency of atrazine-residue detection in relation to 1992 atrazine use in the counties sampled (19) for each of the 31 agricultural land-use studies. Intensity of use was calculated by dividing total mass of active ingredient applied in agricultural settings within the sampled counties by the total area of cropland-including orchards, vineyards, citrus groves, and pasture-in those counties.

(MCL) of $3 \mu \mathrm{g} / \mathrm{L}$ in one well, and dieldrin concentrations exceeded the 10-6 risk-specific dose of $0.002 \mu \mathrm{g} / \mathrm{L}$ (corresponding to a risk of oneadditional person contracting cancer out of one million people) in 14 wells.

The relative infrequency with which pesticides exceeded drinking water criteria, however, may not providea complete assessment of the overall health and environmental risks associated with the presence of pesticides in shallow groundwater. First, water-quality criteria for the protection of human health have only been established for 25 of the 46 pesticide compounds examined for this study (Table 1). Second, thesedrinking water criteria only consider theeffects of individual compounds and do not account for thepresence of morethan one pesticidecompound; somestudies indicate that combinations of pesticide compounds may exhibit additiveor even synergistic toxic effects $(68,69)$. In thisstudy, $73 \%$ of the sampling sites where pesticides were detected had two or more compounds present, $25 \%$ had four or more, and $6 \%$ had six or more compounds present. Third, other pesticide compounds not examined for this study-particularly pesticide degradates-have been detected in groundwater (e.g., refs 37,70 , and 71 ) that also could have potential health effects (e.g., refs 72 and 73). Fourth, recent research also suggests that some pesticide compounds may cause deleterious health effects at levels considered safe by current standards $(67,74,75)$. Finally, drinking water criteria do not account for potential effects of pesticide compounds on aquatic ecosystems (e.g., refs 66 and 76). Several exceedences of criteria for the protection of freshwater aquatic life (14, 77) were observed during the present study (atrazine $\geq 2.0$ $\mu \mathrm{g} / \mathrm{L}$ at four sites; carbaryl $\geq 0.02 \mu \mathrm{g} / \mathrm{L}$ at threesites; diazinon $\geq 0.009 \mu \mathrm{g} / \mathrm{L}$ at five sites; dieldrin $\geq 0.005 \mu \mathrm{g} / \mathrm{L}$ at 13 sites); such exceedences may be significant to the health of aquatic ecosystems receiving groundwater discharge near the sampling locations of interest.

\section{Acknowledgments}

The authors would like to thank all of the members of the NAWQA Study Units, who were responsiblefor selecting and/ or installing the sampling sites, collecting the water samples, furnishing the pesticide data from the 41 land-use studies used for this study, and providing local expertise on their particular study area. The authors would also like to thank Gail Thelin, Naomi Nakagaki, and Kerie Hitt for their work assembling the geographic and pesticide use data employed for this study. In addition, the authors would like to thank Neil Dubrovsky (USGS) and Charles Crawford (USGS) for their critical comments provided during the USGS review process.

\section{Literature Cited}

(1) Larson, S. J.; Capel, P. D.; Majewski, M. S. Pesticides in Surface Waters: Distribution, Trends, and Governing Factors; Ann Arbor Press: Chelsea, MI, 1997; 373 pp.

(2) Majewski, M. S.; Capel, P. D. Pesticides in the Atmosphere: Distribution, Trends, and Governing Factors; Ann Arbor Press: Chelsea, MI, 1995; 214 pp.

(3) Barbash, J. E.; Resek, E. A. Pesticides in Ground Water: Distribution, Trends, and GoverningFactors; Ann Arbor Press: Chelsea, MI, 1996; $588 \mathrm{pp}$.

(4) Walls, D.; Smith, P. G.; Mansell, M. G. Int. J. Environ. Health Res. 1996, 6, 55-62.

(5) Moody, D. W.; Carr, J.; Chase, E. B.; Paulson, R. W. U.S. Geol. Surv. Water-Supply Pap. 1988, No. 2325.

(6) Leahy, P. P.; Rosenshein, J. S.; Knopman, D. S. Open-File Rep.-U.S. Geol. Surv. 1990, No. 90-174.

(7) Gilliom, R. J.; Alley, W. M.; Gurtz, M. E. Geol. Surv. Circ. (U.S.) 1995, No. 1112.

(8) Lapham, W. W.; Wilde, F. D.; Koterba, M. T. Open-FileRep.-U.S. Geol. Surv. 1995, No. 95-398.

(9) Squillace, P. J.; Zogorski, J. S.; Wilber, W. G.; Price, C. V. Environ. Sci. Technol. 1996, 30 (5), 1721-1730.

(10) Scott, J. C. Water-Resour. Invest. (U.S. Geol. Surv.) 1990, No. 90-4101.

(11) Koterba, M.T.; Wilde, F. D.; Lapham, W. W. Open-FileRep.-U.S. Geol. Surv. 1995, No. 95-399.

(12) Zaugg, S. D.; Sandstrom, M. W.; Smith, S. G.; Fehlberg, K. M. Open-File Rep.-U.S. Geol. Surv. 1995, No. 95-181.

(13) U.S. Environmental Protection Agency. Drinking water regulations and health advisories; U.S. Environmental Protection Agency, Office of Water; U.S. Government Printing Office: Washington, DC, 1996.

VOL. 32, NO. 5, 1998 / ENVIRONMENTAL SCIENCE \& TECHNOLOGY - 565 
(14) Nowell, L. H.; Resek, E. A. Open-FileRep.-U.S. Geol. Surv. 1994, No. 94-44.

(15) Martin, J. D.; Gilliom, R. J.; Schertz, T. L. Open-File Rep.-U.S. Geol. Surv. in press.

(16) Coats, J. R. In Pesticide Transformation Products: Fate and Significance in the Environment; Somasundaram, L., Coats, J. R., Eds.; ACS Symposium Series 459; American Chemical Society: Washington, DC, 1991; pp 10-31.

(17) Battaglin, W. A.; Goolsby, D. A. J. Hydrol. 1997, 196, 1-25

(18) Gilliom, R. J.; Thelin, G. P. Geol. Surv. Circ. (U.S.) 1996, No. 1131.

(19) Gianessi, L. P.; Anderson, J. E. Pesticide use in U.S. Crop Production: National Data Report, 1996, Washington, DC; National Center for Food and Agricultural Policy: February 1995 (Revised April 1996)

(20) U.S. Department of Commerce. 1992 Census of AgricultureGeographicArea Series 1B, U.S. Summaryand County Level Data, 1992; U.S. Department of Commerce, Bureau of the Census: Washington, DC, 1992.

(21) Wauchope, R. D.; Buttler, T. M.; Hornsby, A. G.; AugustijnBeckers, P. W. M.; Burt, J. P. Rev. Environ. Contam. Toxicol. 1992, 123, 1-156.

(22) Kearney, P. C.; Nash, R. G.; Isensee, A. R. In Chemical fallout: Current research on persistent pesticides; Miller, M. W., Berg, C. C., Eds.; Charles C. Thomas: Springfield, IL, 1969; pp 54-67.

(23) Stewart, D. K. R.; Chisholm, D. Can. J. Soil Sci. 1971, 61, 379383.

(24) Erickson, L. E.; Lee, K. H. Crit. Rev. Environ. Control 1989, 19 (1), 1-14.

(25) Montgomery, J. H. Agrochemicalsdesk reference: Environmental data; Lewis Publishers: Chelsea, MI, 1993.

(26) Mersie, W.; Seybold, C. J. Agric. Food Chem. 1996, 44, 19251929.

(27) Suntio, L. R.; Shiu, W. Y.; Mackay, D.; Seiber, J. N.; Glotfelty, D. Rev. Environ. Contam. Toxicol. 1988, 103, 1-59.

(28) Kolpin, D. W.; Goolsby, D. A.; Thurman, E. M. J. Environ. Qual. 1995, 24, 1125-1132.

(29) Barbash, J. E. Fact Sheet, U.S. Geol. Surv. 1995, No. 244-95, 4 pp.

(30) Cowdery, T. K. Open-File Rep.-U.S. Geol. Surv. 1995, No. 95441.

(31) Adamski, J. C.; Pugh, A. L. Water Resour. Bull. 1996, 32, 97-105.

(32) Rupert, M. G.; Stone, J. A. J.; Ott, D. S. Fact Sheet, U.S. Geol. Surv. 1996, No. 246-95, 4 pp.

(33) Aspelin, A. L. Pesticides industry sales and usage, 1992 and 1993 market estimates; U.S. Environmental Protection Agency, Office of Pesticide Programs: Washington, DC, 1994; 733-K-94-001; $33 \mathrm{pp}$.

(34) U.S. Environmental Protection Agency. Another look-National survey of pesticides in drinking water wells, phase 2 report; U.S. Environmental Protection Agency, U.S. Government Printing Office: Washington, DC, 1992; EPA/579/09-91/020 (available from National Technical Information Service, Springfield, VA.; as NTIS Report PB 91-125765).

(35) Holden, L. R.; Graham, J. A.; Whitmore, R. W.; Alexander, W. J.; Pratt, R. W.; Liddle, S. K.; Peper, L. L. Environ. Sci. Technol. 1992, 26, 935-943.

(36) Domagalski, J. L.; Dubrovsky, N. M. J. Hydrol. 1992, 130, 299338.

(37) Kolpin, D. W.; Kalkhoff, S. J.; Goolsby, D. A.; Sneck-Fahrer, D. A.; Thurman, E. M. Ground Water 1997, 35, 679-688.

(38) Baker, D. B.; Wallrabenstein, L. K.; Richards, R. P. In New directionsin pesticideresearch, development, management, and policy: Proceedings of the Fourth National Conference on Pesticides; Virginia Polytechnic Institute and State University: Blacksburg, VA, 1994; pp 470-494.

(39) Pesticides in ground water: Background document; U.S. Environmental Protection Agency, U.S. Government Printing Office: Washington, DC, 1986; EPA 440/6-86-002.

(40) Kimbrough, R. A.; Litke, D. W. Environ. Sci. Technol. 1996, 30, 908-916.

(41) Land, L. F. Fact Sheet, U.S. Geol. Surv. 1996, No. FS-178-96.

(42) Agertved, J.; Rugge, K.; Barker, J. F. Ground Water 1992, 30, 500-506.

(43) Nair, D. R.; Schnoor, J. L. Environ. Sci. Technol. 1992, 26, 22982300.

(44) Widmer, S. K.; Spalding, R. F. J. Environ. Qual. 1995, 24, 445453.

(45) Gianessi, L. P.; Puffer, C. Herbicide Use in the United States; Resources for the Future, Inc.: Washington, DC, 1991; 128 pp.

(46) Andrilenas, P. Agricultural Economic Report 252. U.S. Department of Agriculture: 1974
(47) Battaglin, W. A.; Goolsby, D. A. Water-Resour. Invest. (U.S. Geol. Surv.) 1995, No. 94-4176.

(48) Kolpin, D. W.; Thurman, E. M.; Goolsby, D. A. Environ. Sci. Technol. 1996, 30, 335-340.

(49) Kross, B. C.; Hallberg, G. R.; et al. The lowa state-wide rural well-water survey water quality data: Initial analysis; Iowa Department of Natural Resources Technical Information Series 19; 1990; $142 \mathrm{pp}$.

(50) LeMasters, G. L.; Doyle, D. J. Grade A Dairy Farm Well Water Quality Survey; Wisconsin Department of Agriculture and Wisconsin Agricultural Statistics Service: Madison, WI, 1989; $36 \mathrm{pp}$.

(51) Koelliker, J. K.; Steichen, J. M.; Yearout, R. D.; Heiman, A. T.; Grosh, D. L. Identification of factors affecting farmstead well water quality in Kansas; Kansas State University, Kansas Water Resources Research Institute: 1987; $50 \mathrm{pp}$.

(52) Carter, D. S.; Lydy, M. J.; Crawford, C. G. Water-Resour. Invest. (U.S. Geol. Surv.) 1995, No. 94-4024.

(53) Bell, R. W.; Joseph, R. L.; Freiwald, D. A. Water-Resour. Invest. (U.S. Geol. Surv.) 1996, No. 96-4003.

(54) Zimmerman, M. J.; Grady, S. J.; Trench, E. C. T.; Flanagan, S M.; Nielsen, M. G. Water-Resour. Invest. (U.S. Geol. Surv.) 1996, No. $95-4203$.

(55) Southwick, L. M.; Willis, G. H.; Selim, H. M. Bull. Environ. Contam. Toxicol. 1990, 45, 1264-1268.

(56) Troiano, J.; Garretson, C.; Krauter, C.; Brownell, J.; Huston, J. J. Environ. Qual. 1993, 22, 290-298.

(57) Wietersen, R. C.; Daniel, T. C.; Fermanich, K. J.; Lowery, B.; McSweeney, K. J. Environ. Qual. 1993, 22, 819-824.

(58) Kolpin, D. W. J. Environ. Qual. 1997, 26, 1025-1037.

(59) Domagalski, J. L.; Dubrovsky, N. M. Water-Resour. Invest. (U.S. Geol. Surv.) 1991, No. 91-4027, 64 pp.

(60) Healy, D. F. Water-Resour. Invest. (U.S. Geol. Surv.) 1996, No. 95-4069.

(61) Pasquarell, G. C.; Boyer, D. G. J. Environ. Qual. 1996, 25, 755765.

(62) Burkart, M. R.; Kolpin, D. W. J. Environ. Qual. 1993, 22, 646656.

(63) Ator, S. W.; Ferrari, M. J. Water-Resour. Invest. (U.S. Geol. Surv.) 1997, No. 97-4139.

(64) Howard, P. H., Ed. Handbook of Environmental Fate and Exposure Data for Organic Chemicals, Volume III, Pesticides; Lewis Publishers, Inc.: Chelsea, MI, 684 pp.

(65) Mullaney, J. R.; Melvin, R. L.; Adamik, J. T.; Robinson, B. R.; Frink, C. R. Conn. Water Resourc. Bull. 1991, No. 42, 40 pp.

(66) Goodbred, S. L.; Gilliom, R.J.; Gross, T. S.; Denslow, N. P.; Bryant, W. B.; Schoeb. T. R. Open-File Rep.-U.S. Geol. Surv. 1997, No. 96-627.

(67) LeBlanc, G. A.; Bain, L. J.; Wilson, V. S. Mol. Cell. Endocrinol 1997, 126, 1-5.

(68) Marinovich, M. F.; Ghilardi, R.; Galli, C. L. Toxicology 1996, 108 201-206

(69) Thompson, H. M. Ecotoxicology 1996, 5, 59-81.

(70) Barret, M. R. In Herbicide metabolites in surface water and groundwater; Meyer, M. T., Thurman, E. M., Eds.; ASC Symposium Series 630; American Chemical Society: Washington, DC, 1996; pp 200-225.

(71) Potter, T. L.; Carpenter, T. L. Environ. Sci. Technol. 1995, 29, 1557-1563.

(72) Bain, L. J.; LeBlanc, G. A. Toxicol. Appl. Pharmacol. 1996, 141, 288-298.

(73) Tessier, D. M.; Clark, J. M. J. Agric. Food Chem. 1995, 43, 25042512.

(74) Biradar, D. P.; Rayburn, A. L. J. Environ. Qual. 1995, 24, 12221225.

(75) Sawicki, B.; Dewitte, J. D.; Riche, C.; Leglise, M. C. Cell Biol. Toxicol. 1995, 11, 207.

(76) Juttner, I.; Peither, A.; Lay, J. P.; Kettrup, A.; Ormerod, S. J. Arch. Environ. Contam. Toxicol. 1995, 29, 435-441.

(77) Canadian Council of Resource and Environment Ministers. Canadian water qualityguidelines; Environment Canada, Inland Waters Directorate, Water Quality Branch: Ottawa, Ontario, 1991.

(78) The features of these land-use studies are described at http:// water.wr.usgs.gov/pnsp/index.html.

Received for review May 12, 1997. Revised manuscript received November 6, 1997. Accepted November 24, 1997.

ES970412G 